\title{
Komunikasi Antar Pribadi Guru Bimbingan dan Konseling dengan Siswa Bermasalah
}

\author{
Hariansyah*) \\ SMA Muhammadiyah 09Kualuhhulu, Labuhanbatu Utara, Sumatera Utara, Indonesia \\ koresponden: asahanhariansyah@gmail.com
}

\begin{abstract}
ABSTRAK
Penelitian bertujuan untuk melihat bagaimana penggunaan komunikasi Antar Pribadi yang dilakukan guru bimbingan dan konseling terhadap siswa yang bermasalah di SMA Muhammadiyah SMA Muhammadiyah 09 Kualuhhulu, Kabupaten Labuhan Batu. Pendekatan penelitian dengan menggunakan metode kualitatif dengan teknik wawancara dan observasi dan menghasilkan kesimpulan bahwa bentuk komunikasi antara guru bimbingan dan konseling serta siswa yang bermasalah berupa komunikasi verbal dan komunikasi nonverbal dengan cara mengkomunikasikan pesannya secara verbal atau dengan lisan melalui program pembelajaran yang telah ditetapkan, sedangkan komunikasi nonverbal antara siswa dan guru terjadi sebagai proses pertukaran pikiran dan gagasan dimana pesan yang disampaikan berupa isyarat, ekspresi wajah, pandangan mata, gerakan tubuh dan sentuhan. Efektivitas komunikasinya memiliki kredibilitas (source credibility). Namun tetap terdapat faktor-faktor yang menjadi pendukung dan penghambat komunikasi antarpribadi antara guru bimbingan dan konseling dalam mengatasi siswa yang bermasalah
\end{abstract}

Kata Kunci: Komunikasi Antar Pribadi, Komunikasi Verbal, Konseling

\begin{abstract}
The research aims to see how the use of interpersonal communication by teachers of guidance and counseling of students with problems in Muhammadiyah High School Muhammadiyah 09 Kualuhhulu High School, Kab. Labuhan Batu. The research approach uses qualitative methods with interview and observation techniques and produces conclusions that the form of communication between guidance and counseling teachers and students who have problems in the form of verbal communication and nonverbal communication by communicating the message verbally or verbally through a predetermined learning program, while communication nonverbal between students and teachers occurs as a process of exchange of thoughts and ideas where the message conveyed in the form of cues, facial expressions, eye sight, body movements and touch. The effectiveness of the communication has credibility (source credibility). But there are still factors that support and inhibit interpersonal communication between teacher guidance and counseling in dealing with students who have problems.
\end{abstract}

Keywords: Interpersonal Communication, Verbal Communication, Counseling

\section{Pendahuluan}

Perubahan sikap dan tingkah laku remaja dapat diselesaikan melalui pelaksanaan komunikasi antarpribadi yang dilakukan oleh guru bimbingan dan konseling yang ada di sekolah. Hal ini sangat dimungkinkan karena komunikasi antarpribadi merupakan satu bentuk komunikasi yang mempunyai keistimewaan tersendiri yakni pada umumnya antara 
komunikator dan komunikan saling berhadapan langsung. Oleh karena itu tingkat pengamatan keduanya cenderung sangat tinggi.

Bimbingan dan konseling merupakan kegiatan yang bersumber pada kehidupan manusia. Kenyataan menunjukkan bahwa manusia di dalam kehidupannya menghadapi persoalan-persoalan yang silih berganti. Bimbingan dan konseling merupakan satu bentuk kegiatan komunikasi yang bertujuan untuk merubah sikap dan tingkah laku siswa. Bimbingan ialah bantuan yang diberikan kepada seseorang individu untuk menentukan tujuannya, baik jangka pendek maupun jangka panjang, merancang cara-cara bertindak dan memperbaiki sikap serta tingkah laku dalam aspek-aspek yang dirasa perlu oleh individu itu.

Menurut Prayitno (2004:105), konseling adalah proses pemberian bantuan yang dilakukan melalui wawancara konseling oleh seorang ahli (disebut konselor) kepada individu yang sedang mengalami sesuatu masalah (klien) yang bermuara pada teratasinya masalah yang dihadapi klien. Meski saat ini paradigma pelayanan bimbingan dan konseling lebih mengedepankan pelayanan yang bersifat pencegahan dan pengembangan, pelayanan bimbingan dan konseling terhadap siswa yang bermasalah tetap masih menjadi perhatian. Adapun beberapa contoh masalah yang ditangani guru bimbingan dan konseling di SMA Muhammadiyah 09 Kualuhhulu di antaranya berupa:

1. Membolos, malas sekolah, merokok, kesulitan belajar pada bidang tertentu, berkelahi dengan teman sekolah, bertengkar, meminum minuman keras tahap awal, berpacaran dan mencuri kelas ringan.

2. Masalah kasus berat seperti: gangguan emosional, berpacaran, dengan perbuatan menyimpang, hamil, berkelahi antarsekolah, kesulitan belajar karena gangguan dalam keluarga, meminum minuman keras yang sudah mengalami kecanduan, serta melakukan gangguan sosial dan asusila.

Inilah contoh beberapa kasus yang pernah ditangani guru bimbingan dan konseling. Pihak SMA Muhammadiyah 09 Kualuhhulu dalam menciptakan proses belajar mengajar yang baik serta mewujudkan siswa yang berdisiplin tinggi dan berprestasi baik, senantiasa mengaktifkan kegiatan guru bimbingan dan konselingnya dalam menangani siswa-siswa yang bermasalah. Pelaksanaan komunikasinya dalam bentuk komunikasi antarpribadi dan bersifat dialogis untuk mengetahui lebih banyak penyebab siswa melakukan kesalahan.

Keberhasilan bagian bimbingan dan konseling di SMA Muhammadiyah 09 Kualuhhulu dalam menangani siswa yang bermasalah begitu penting dengan cara menerapkan komunikasi antarpribadi yang dilakukan oleh guru bimbingan dan konseling. Dengan demikian perlu diketahui bagaimana penerapan dan faktor penghambat komunikasi antarpribadi yang dilakukan oleh para guru bimbingan dan konseling.

\section{Metode}

Penelitian ini menggunakan metode dengan pendekatan kualitatif. Pengumpulan data dalam penelitian ini ditriangulasikan dengan menggunakan dan mengkombinasikan lebih dari satu teknik pengumpulan data yang berbeda demi keabsahan data yang diperoleh (Lancaster, 2005:42). Adapun instrumen pengumpulan data yang digunakan dalam penelitian ini dalam usaha untuk memperoleh data-data yang dibutuhkan untuk dijadikan sebagai bahan dalam menganalisa masalah yang diteliti yaitu, wawancara, observasi terhadap bentuk-bentuk komunikasi antara guru bimbingan dan konseling dan siswa yang bermasalah di SMA Muhammadiyah 09 Kualuhhulu, efektivitas komunikasi antara guru bimbingan dan konseling dan siswa yang bermasalah, langkah-langkah penanganan yang 
dilakukan guru bimbingan dan konseling, faktor-faktor yang menjadi pendukung dan penghambat komunikasi antarpribadi antara guru bimbingan dan konseling dalam mengatasi siswa serta upaya-upaya guru bimbingan dan konseling dalam mengatasi siswa yang bermasalah di SMA Muhammadiyah 09 Kualuhhulu Kabupaten Labuhanbatu Utara. Sumber perolehan data lapangan, maka data yang merupakan objek dalam penelitian ini dibagi pada dua bagian, yaitu data primer yang diperoleh dari SMA Muhammadiyah 09 Kualuhhulu, yaitu guru Bimbingan dan Konseling (Ibu Ulianna, S.Pd), serta siswa bermasalah yang menjadi informan dengan jumlah 18 (delapan belas) orang siswa SMA Muhammadiyah 09 Kulaluhhulu dan data pelengkap sebagai pendukung dalam penelitian yang dapat dipeloreh dari Kepala Sekolah (Bapak H. Abdul Kamal Munthe, S.H), orang tua siswa-siswi yang bermasalah, dan arsip/dokumen yang mendukung penelitian ini, buku-buku maupun jurnal-jurnal. Lokasi penelitian ini dilaksanakan di SMA Muhammadiyah 09 Kualuhhulu, Jl. Ghazali Sinaga No.3 Kecamatan Kualuhhulu Kabupaten Labuhanbatu Utara, Sumatera Utara, mulai bulan Februari sampai dengan bulan Juni tahun 2013.

\section{Hasil dan Pembahasan}

Berdasarkan hasil penelitian bahwa para guru mengkomunikasikan pesannya secara verbal atau dengan lisan melalui program pembelajaran yang telah ditetapkan. Komunikasi yang diberlakukan dapat berlangsung melalui bentuk komunikasi verbal dalam rentang komunikasi yang informal sampai yang formal.

Komunikasi verbal yang dilakukan guru bimbingan dan konseling di SMA Muhammadiyah 09 Kualuhhulu dilakukan dengan cara menasehati siswa secara langsung, sebagaimana pengamatan penulis pada tanggal 8 Mei 2013 terhadap kegiatan bimbingan dan konseling yang dilakukan Ibu Ulianna, S.Pd disaat memberikan nasehat kepada Syahri Ramadani Siahaan, siswa kelas X SMA Muhammadiyah 09 Kualuhhulu yang sering bolos, padahal orang tuanya beranggapan bahwa anaknya senantiasa mengikuti pembelajaran dengan tekun. Berikut nasehat Ibu Ulianna:

"Ingatlah Syahri! Bayangkan engkau berada dalam dekapan ibumu, sentuh dan rasakan olehmu keriput tangan ibu-ibumu. Dengan penuh kasih, tangan keriput itu mengelus-elus kepalamu dan berdoa akan kesuksesan masa depanmu. Tidakkah engku menyadari, dengan gemetar ibumu berkata "Syahri, sekarang kamu sudah besar, jadilah kamu anak yang sholeh, anak yang berguna, yang bisa menjadi kebanggaan ibu nak. Jadilah anak yang hormat kepada guru dan kedua orang tuamu ini, dan jadilah anak yang penuh kasih sayang terhadap sesama". Syahri, dalam hati di setiap waktu ibumu selalu memohon "Ya Allah Tuhan yang Maha Mendengar, jadikanlah anakku anak yang sholeh ya Robb!" Syahri!, mungkin engkau tidak pernah tau. Setiap detik, setiap menit, doa kebaikanlah yang selalu teruntai dari bibir ibumu. Walau ibumu sadar sikap dan kata-kata yang sering kalian lontarkan, banyak menyakiti hati ibumu. Sampai-sampai membuat kedua kelopak mata ibumu basah, dia menangis, tak kuasa menahan sedih atas sikapsikapmu. Sesakit apapun hati ibumu, apa yang ibumu lakukan adalah untukmu. Saat engkau tertidur nyenyak, ibumu terjaga dari tidurnya, dia menatap kalian dengan penuh kasih, dia selimuti kalian. Dan tidak lupa bersujud dalam keheningan malam. Saya tau betul kalau ibumu seperti itu Syahri! Ibumu selalu menanyakan dan menelepon saya! Betapa mulianya sosok ibumu. Betapa sayang dan perhatianya ibu-ibumu. Bayangkan! Sembilan bulan engkau ada dalam kandunganya, rasa sakit yang tiada bandinganya, dirasakan sendiri oleh ibumu saat melahirkan engkau. Dan, sampai sekarang, tetap saja 
engkau membuat susah ibumu. Membuat marah ibumu, bahkan engkau buat ibumu sedih. Coba kau bertanya pada hatimu! Siapa yang selalu menyiapkan sarapan untukmu? Siapa yang mencuci dan menyeterika pakaianmu? Siapa yang menjaga kalian disaat sakit? Tetapi, apa yang telah engkau berikan untuk ibumu? Hanya cuek dan malah bolos sekolah!".

Selain komunikasi verbal yang didapat dalam penelitian ini juga terdapat komunikasi nonverbal. Berdasarkan hasil riset, komunikasi nonverbal antara siswa dan guru terjadi sebagai proses pertukaran pikiran dan gagasan yang mana pesan yang disampaikan berupa isyarat, ekspresi wajah, pandangan mata, gerakan tubuh dan sentuhan. Komunikasi nonverbal seperti halnya guru memberikan senyuman kepada siswa ketika bertemu, ini menunjukkan bahwa adanya keharmonisan antara guru dan siswa, sehingga tercapailah komunikasi yang efektif dan baik. Untuk itu jelas bahwa komunikasi antara guru dan siswa sangat penting demi kemajuan pendidikan siswanya.

Beberapa hal pokok terkait perilaku nonverbal guru bimbingan dan konseling yang penulis amati di SMA Muhammadiyah 09 Kualuhhulu Kabupaten Labuhanbatu Utara yang harus lebih dieksplorasi adalah: 1) Kontak pandang. 2) Ekspresi wajah. 3) Gesture (gerak tubuh). 4) Orientasi tubuh dan postur. 5) Kedekatan. 6) Paralinguistic. 7) Humor. Kontak pandang adalah chanel penting pada sebuah komunikasi antarpribadi di SMA Muhammadiyah 09 Kualuhhulu Kabupaten Labuhanbatu Utara, karena sangat membantu mengatur arah komunikas dan sinyal-sinyalnya menarik bagi siswa. Selain itu kontak pandang antara guru dengan siswa lebih meningkatkan kredibilitas guru. Guru bimbingan dan konseling yang melakukan kontak pandang dengan siswa telah membuka arah komunikasi dan nenunjukkan minat, perhatian, kehangatan, dan kredibilitas.

Ekspresi wajah seperti senyum yang dilakukan guru bimbingan dan konseling SMA Muhammadiyah 09 Kualuhhulu Kabupaten Labuhanbatu Utara adalah isyarat yang dapat menghantarkan kebahagian, persahabatan, kehangatan, rasa suka dan afiliasi, sehingga jika seorang guru bimbingan dn konseling tersenyum lebih sering, maka siswa tidak lagi menganggap guru bimbingan dan konseling sebagai momok yang menakutkan, melainkan guru bimbingan dan konseling dianggap sebagai penyuka (mudah menyukai), bersahabat, mudah menerima, dan dapat didekati.

Selain ekspresi wajah, gesture (gerak tubuh) juga sangat penting dalam komunikasi nonverbal guru bimbingan dan konseling SMA Muhammadiyah 09 Kualuhhulu Kabupaten Labuhanbatu Utara. Bila guru tidak dapat memberikan gesture ketika berbicara, guru bimbingan dan konseling dapat saja dianggap membosankan dan kaku. Gaya nasehat yang hidup akan menangkap perhatian siswa yang bermsalah di konseling SMA Muhammadiyah 09 Kualuhhulu Kabupaten Labuhanbatu Utara.

Orientasi tubuh dan postur guru bimbingan dan konseling SMA Muhammadiyah 09 Kualuhhulu Kabupaten Labuhanbatu Utara juga mengkomunikasikan banyak pesan dengan cara berjalan, bicara, berdiri dan duduk. Berdiri tegak tetapi tidak kaku, dan bertumpu dengan ringan pada meja guru, menunjukkan bahwa guru dapat didekati, menunjukkan penerimaan, dan bersahabat. Lebih jauh, kedekatan antarpribadi antara guru dengan siswa akan tercipta saat kita berbicara face-to-face (berhadapan) satu sama lain.

Kegiatan bimbingan konseling di SMA Muhammadiyah 09 Kualuhhulu Kabupaten Labuhanbatu Utara merupakan suatu kegiatan untuk mendorong dan mengembangkan siswa agar tidak terjadi kenakalan siswa. Kegiatan ini dilaksanakan menurut kurikulum yang berlaku pada sekolah umum lainnya. Bila dilihat dari sarana dan prasarana sekolah, kegiatan tersebut sudah mencukupi standar kualitas proses bimbingan dan konseling. 
Dengan demikian pada kegiatan tersebut bisa berjalan dengan efektif. Terdapat faktorfaktor sarana dan prasarana yang baik, seorang siswa dapat melaksanakan kegiatankegiatan yang positif pula, sehingga hal-hal negatif tidak akan terjadi. Begitu pula dalam pelaksanaan bimbingan konseling. Informasi yang diberikan dalam bentuk pesan dan simbol pada kegiatan bimbingan dan konseling, disusun dalam bentuk materi yang sesuai dengan norma-norma yang berlaku di masyarakat pada umunya. Diharapkan dari pemberian materi tersebut muncul respon positif dari siswa agar tidak melakukan tindak kenakalan. Dalam tatanan komunikasi terdapat komunikasi antarpribadi yaitu proses pengiriman serta penerimaan pesan-pesan antara dua orang atau di antara sekelompok kecil orang, tentunya dengan beberapa efek dan beberapa umpan balik seketika. Oleh karena itu semua hal-hal terkecil pun yang bisa menunjang pelaksanaan bimbingan dan konseling akan dilaksanakan, demi terlaksananya bimbingan yang efktif dan sempurna. Untuk itu diperlukan komunikasi yang cukup intensif dari pendidik di dalam mendidik agar nantinya terbentuk manusia yang dewasa yang mampu membaca lingkungan dan dapat menghadapi permasalahan-permasalahan yang timbul di sekitarnya.

Di dalam mendidik dan mengasuh anak-anak remaja, pendidik diharapkan lebih berperan melalui komunikasi secara pribadi dengan anak remaja yang bersangkutan. Karena dengan memahami sifat dan karakter remaja yang bersangkutan akan lebih mempermudah dan memperlancar komunkasi dengan mereka. Komunikasi antarpribadi yang dilakukan oleh guru merupakan suatu pembicaraan secara pribadi yang dilakukan oleh guru terhadap salah satu siswa yang memerlukan perhatian penuh dan nasehatnasehat, untuk dapat mengatasi masalah yang dihadapi oleh siswa tersebut. Misalnya masalah pribadi, masalah dengan temannya, maupun masalah akademis. Hal tersebut dilakukan guru Bimbingan dan Konseling (BK) sebagai arahan dan langkah-langkah dalam mengatasi masalah-masalah yang mereka hadapi, agar siswa mampu dalam menyelesaikan masalah dan berkomunikasi seperti biasa dengan teman-teman yang lain dan juga mampu menerima materi-materi pelajaran yang disampaikan oleh guru-guru lainnya.

Dikatakan komunikasi tersebut berjalan dengan efektif, karena dilihat dari proses penyampaian bimbingan yang terjadi ketika seorang guru menyampaikan materi bimbingannya. Selain itu Peneliti juga menemukan beberapa point penting dalam penelitian tersebut. Adapun dari hasil penelitian yang penulis lakukan dengan cara wawancara dengan siswa, kebanyakan siswa menyatakan komunikasi antarpribadi yang terjadi di sekolah tersebut adalah sangat penting dan efektif. Sebelum melaksanakan bimbingan, guru terlebih dahulu melihat latar belakang kehidupan sosial keluarganya. Sehingga pesan-pesan tersebut akan menimbulkan suatu komunikasi yang baik dan mudah dimengerti oleh siswa-siswinya. Terdapat faktor-faktor yang menunjang komunikasi antar pribadiyang efektif bisa dilihat dari segi:

\section{Komunikator}

Komunikator harus memiliki kredibilitas (source credibility). Jika dalam hal ini guru tidak memiliki kredibilitas maka siswa akan sulit menerima pesan yang disampaikan oleh guru, bahkan siswa tidak mau mengikuti perintah guru. Selain itu guru harus memiliki daya tarik (source attractiveness). Siswa akan dengan mudah menerima pesan yang disampaikan oleh guru karena siswa merasa bangga terhadap gurunya dan mengagumi sosok gurunya. Sebagaimana hasil wawancara penulis dengan Ibu Ulianna, S.Pd yang merupakan komunikator sekaligus selaku guru bimbingan dan konseling di SMA Muhammadiyah 09 Kualuhhulu yang penulis wawancarai pada tanggal 7 Mei 2013: 
"Menurut saya sudah efektif, karena kami melakukan pendekatan-pendekatan pada siswa itu sendiri. Sehingga siswa tersebut merasa kalau kami merupakan panutan atau contoh. Tidak lupa kami selalu menjalin komunikasi dengan siswa tersebut. Agar kami mendapatkan dukungan serta kepercayaan dari orang tua siswa sehingga jika ada siswa yang bermasalah kami dengan mudah menyelesaikannya”.

\section{Pesan}

Pesan harus dirancang dan disampaikan dengan sedemikian rupa sehingga menarik bagi siswa, pesan harus menggunakan lambang-lambang yang dapat dipahami oleh siswa, pesan harus sesuai dengan kebutuhan siswa. Jadi guru harus mengemas pesan dengan baik, jangan sampai terjadi miss understanding antara guru dan siswa.

\section{Komunikan}

Siswa mau mendengarkan atau berkonsentrasi agar pesan dapat diterima dengan benar, sehingga siswa bersedia mengambil keputusan pada saat komunikasi berlangsung, dan memberikan umpan balik kepada guru. Sudah popular di Indonesia bahwa tujuan pendidikan nasional pada khususnya dan pembangunan kepada umumnya adalah ingin menciptakan "manusia seutuhnya". Maksudnya manusia yang lengkap, selaras, serasi, dan seimbang perkembangan semua segi kepribadiannya. Sedangkan dalam pelaksanaan bimbingan, guru sering menggunakan dialog dengan siswanya, karena dialog merupakan bentuk komunikasi antarpribadi yang menunjukkan terjadinya interaksi. Mereka yang terlibat dalam komunikasi bentuk ini berfungsi ganda. Masing-masing menjadi pembicara dan pendengar secara bergantian.

Berdasarkan hasil penelitian penulis selama melakukan penelitian di SMA Muhammadiyah 09 Kualuhhulu Kabupaten Labuhanbatu Utara, bahwa dalam proses komunikasi tampak adanya upaya perilaku komunikasi untuk terjadinya pengertian bersama dan empatinya. Guru malakukan shared face to face pada siswa atau siswi, menasihati atau menegur anak tersebut secara baik dan membantu siswa atau siswi untuk mengkontrol diri. Dalam komunikasi antarpribadi sangat ampuh dibanding bentuk komunikasi lainnya karena terjadi kontak pribadi. Ketika guru menyampaikan pesan, umpan balik berlangsung seketika. Guru mengetahui pada saat itu tanggapan muridnya, terhadap pesan yang telah disampaikan.

Penulis juga mewawancarai Ismanto, yang merupakan komunikan dari guru bimbingan dan konseling. Ismanto merupakan siswa kelas XI IPA di SMA Muhammadiyah 09 Kualuhhulu yang penulis wawancarai pada tanggal 10 Mei 2013:

"Termasuk efektif, karena dalam hal komunikasinya sangat efektif, tetapi dalam penerapannya kurang efektif. Karena banyak sekali siswa yang sudah berkomunikasi dengan guru masih melakukan kenakalan siswa".

Selain itu, penulis juga mewawancarai Surya Wardana, siswa kelas XI IPA di SMA Muhammadiyah 09 Kualuhhulu yang penulis wawancarai pada tanggal 10 Mei 2013:

"Komunikasi antarpribadi guru dan siswa sudah cukup baik, tapi karena siswa banyak yang masih selalu ingin senang dan sesukanya hal itu sedikit sekali efektifnya."

Keuntungan bagi seorang guru dalam menggunakan komunikasi antarpribadi dalam penyampaian materi bimbingan terdapat kontak langsung secara pribadi, umpan balik secara langsung dan suasana lingkungan komunikasipun segera dapat diketahui, sehingga guru dapat mengetahui tanggapan dan reaksi murid pada saat menyampaikan materi bimbingan. Penulis menjelaskan operasionalisasi dari efketivitas komunikasi antarpribadi yang terdapat pada lima karakteristik adalah: 
1. Keterbukaan, setiap siswa di SMA Muhammadiyah 09 Kualuhhulu Kabupaten Labuhanbatu Utara yang memiliki masalah pelajaran ataupun masalah pribadi selalu bercerita kepada guru.

2. Empati, maksudnya seorang guru yang baik harus bisa menempatkan posisi dan merasakan keluhan yang sedang dihadapi siswanya.

3. Dukungan, maksudnya guru di SMA Muhammadiyah 09 Kualuhhulu Kabupaten Labuhanbatu Utara terutama guru bimbingan dan konseling (BK) selalu mendukung setiap kegiatan siswa, yang tentunya kegiatan-kegiatan tersebut bersifat positif.

4. Rasa positif, guru bimbingan dan konseling BK di SMA Muhammadiyah 09 Kualuhhulu Kabupaten Labuhanbatu Utara memiliki rasa positif terhadap siswa yang bermasalah. Karena mereka berpendapat bahwa setiap siswa dapat berubah kalau dibimbing dengan baik

5. Kesamaan, guru bimbingan dan konseling BK memiliki kesamaan terhadap siswa. Misalnya guru menginginkan siswanya naik kelas dan lulus dengan nilai yang baik begitu juga dengan siswa. Berarti guru dan siswa memiliki kesamaan tujuan.

Secara esensial, sebenarnya guru yang mengajar adalah menyediakan kondisi yang kondusif agar masing-masing individu anak didik itu dapat belajar secara optimal, sehingga tidak melakukan tindak kenakalan. Sehubungan dengan permasalahan tersebut, memang sangat perlu diketahui adanya karakteristik siswa. Karakteristik siswa adalah keseluruhan kelakuan dan kemampuan yang ada pada siswa sebagai hasil dari pembawaan dan lingkungan sosialnya sehingga menentukan pola aktivitas dalam melatih cita-citanya.

Upaya guru bimbingan dan konseling dalam mengatasi siswa yang bermasalah adalah usaha-usaha yang dilakukan guru bimbingan dan konseling dalam memberikan bimbingan dan pengarahan kepada siswa sesuai dengan faktor apa yang melatarbelakangi munculnya permasalahan pada diri siswa tersebut dengan pendekatan komunikasi. Secara umum, berdasarkan hasil riset upaya bimbingan dan konseling dalam mengatasi siswa yang bermasalah biasanya dilakukan dengan cara mencari data dimaksudkan untuk mengetahui siswa-siswi yang bermasalah, sehingga guru bimbingan dan konseling bisa mengetahui faktor-faktor penyebabnya. Guru bimbingan dan konseling dapat menentukan bagaimana membantu permasalahan siswa. Untuk mengetahui data-data siswa guru bimbingan dan konseling melihat dari:
a. Absensi
b. Daftar nilai
c. Data-data dari wali kelas atau guru

Sebagaimana hasil wawancara dengan Ibu Ulianna, S.Pd selaku guru bimbingan dan konseling di SMA Muhammadiyah 09 Kualuhhulu yang diwawawancarai pada tanggal 7 Mei 2013:

"Untuk mengetahui siswa yang bermasalah kita melihat dari 1) absensi 2) prestasi belajar 3) catatan dari wali kelas 4) kemudian baru kita panggil atau kita datangi rumahnya.."

Setelah mengetahui siswa-siswi yang mengalami permasalahan, kemudian guru bimbingan dan konseling memanggil siswa tersebut ke ruang BK. Dalam hal ini guru bimbingan dan konseling tidak menanyakan langsung kepada siswa tentang permasalahan yang dialaminya, guru bimbingan dan konseling hanya mengajak siswa tersebut berkomunikasi secara lisan. Peneliti melakukan wawancara dengan Ibu Ulianna, S.Pd selaku guru bimbingan dan konseling di SMA Muhammadiyah 09 Kualuhhulu yang penulis wawancarai pada tanggal 7 Mei 2013: 
"Kalau misalnya ada siswa yang bermasalah, kita panggil siswa tersebut akan tetapi tidak kita korek atau kita tanya tentang permasalahnnya, tetapi kita ajak berkomunikasi supaya siswa menceritakan sendiri permasalahannya. Untuk itu permasalahn itu dari siswa dan jawabannya untuk siswa. Usaha yang kita lakukan yaitu kita panggil siswa tersebut, kita ajak berkomunikasi kalau perlu kita datangi kerumahnya, mengapa dia mempunyai permasalahan seperti itu, apakah karena faktor keluarga yang selalu menjadi faktor penentu dalam proses belajar".

Guru bimbingan dan konseling dapat mengenali peserta didik yang mengalami berbagai permasalahan seperti kesulitan belajar, memahami sifat dan jenis kesulitan belajarnya dan juga menentukan latar belakang permasalahannya. Jika permasalahan tersebut berupa kesulitan belajar, guru bimbingan dan konseling akan menetapkan usahausaha bantuan, dalam menentukan bantuan apa yang harus diberikan kepada siswa-siswi yang bermasalah, guru bimbingan dan konseling harus mengetahui faktor-faktor penyebabnya. Pada pemaparan di atas telah dijelaskan faktor-faktor yang menyebabkan siswa yang bermasalah yaitu: 1) faktor lingkungan yang meliputi, lingkungan keluarga, lingkungan sekolah, dan lingkungan masyarakat. 2) faktor yang timbul dari dalam diri siswa itu sendiri. Untuk mengatasi permasalahan siswa yang bermasalah ini, guru bimbingan dan konseling melakukan pendekatan dengan siswa tersebut, dalam pendekatan ini, guru bimbingan dan konseling menyesuaikan dengan faktor penyebabnya. Di bawah ini akan dijelaskan upaya guru bimbingan dan konseling dalam mengatasi siswa yang bermasalah, dalam hal ini guru bimbingan dan konseling melakukan pendekatan sesuai dengan faktor penyebabnya.

Mengenai masalah ini, peneliti juga melakukan wawancara dengan Bapak H. Abdul Kamal Munthe, S.H selaku kepala SMA Muhammadiyah 09 Kualuhhulu yang penulis wawancarai pada tanggal 8 Mei 2013, mengatakan bahwa: "Selain memberi bimbingan kepada anak, guru bimbingan dan konseling juga memberikan: 1) membekali anak-anak dengan menanamkan dasar agama yang kuat, dan juga memberikan wawasan kepada anak supaya dia berpikir mandiri da menyelesaikan permasalahannya sendiri secara dewasa. 2) kebijaksanaan untuk siswa, yang dimaksud disini adalah memberikan kebijakan kepada siswa yang prestasinya menurun karena faktor keluarga, terkadang ada siswa yang latar belakngnya dari keluarga yang tidak mampu sehingga dapat juga mempengaruhi semangatnya dalam belajar. Pihak sekolah akan memberi keringanan untuk siswa tersebut".

Berdasarkan hasil penelitian, kebanyakan siswa yang bermasalah dipengaruhi oleh keadaan lingkungan sekolah, faktor ini muncul dari keadaan di dalam kelas, seperti yang telah dipaparkan sebelumnya bahwa suasana kelas yang berisik atau metode yang digunakan guru kurang menyenangkan bagi siswa. Untuk mengatasi permasalahan yang muncul dari guru bidang studi, maka guru bimbingan dan konseling bekerjasama dengan guru bidang studi tertentu, agar guru tersebut mengubah metode pengajaran di kelas, yakni metode yang dapat diterima oleh murid, sehingga murid merasa nyaman di kelas dan belajar bisa tenang. Dalam hal ini peneliti melakukan wawancara dengan Ibu Ulianna, S.Pd selaku guru bimbingan dan konseling di SMA Muhammadiyah 09 Kualuhhulu yang penulis wawancarai pada tanggal 8 Mei 2013:

Faktor ini muncul bukan karena dipengaruhi oleh lingkungan di sekitar siswa tersebut, akan tetapi muncul dari dalam diri siswa itu sendiri. Untuk mengatasi masalah yang timbul dari dalam diri siswa sendiri, guru Bimbingan dan Konseling melakukan pendekatan dan mengarahkannya serta memberikan motivasi agar anak tersebut betul-betul 
semangat untuk belajar. Karena nilai atau angka tidak bisa menjadi patokan kemampuan seorang siswa, setelah mengetahui prestasi siswa-siswi yang rendah, guru bimbingan dan konseling tidak bisa langsung menyimpulkan bahwa siswa tersebut tidak mampu, akan tetapi prestasi siswa menurun dikarenakan faktor-faktor tertentu seperti yang dijelaskan pada pemaparan sebelumnya. Dalam hal ini peneliti melakukan wawancara dengan Bapak H. Abdul Kamal Munthe, S.H selaku kepala SMA Muhammadiyah 09 Kualuhhulu yang penulis wawancarai pada tanggal 8 Mei 2013 mengatakan bahwa:

“...jangan berpegangan pada angka, siswa yang bermasalah ini belum tentu termasuk kategori yang IQ-nya rendah, akan tetapi prestasi yang ia peroleh di bawah ratarata atau rendah. Dalam hal ini guru tidak harus beranggapan bahwa siswa tersebut tidak mampu, karena nilai atau angka tidak bisa jadi patokan atas keampuan seorang anak, bisa jadi siswa tersebut dipengaruhi oleh faktor lain".

Menurut jawaban dari siswa-siswi kelas XI IPA DAN XII IPA yang penulis wawancarai pada tanggal 7 Mei 2013 mengatakan bahwa:

"Upaya yang dilakukan guru bimbingan dan konseling adalah memberikan pengarahan, memotivasi dan membantu menyelesaikan permasalahan yang dihadapi oleh siswa. Guru bimbingan dan konseling mengajak bicara atau ada yang mengatakan kelas curhat, jadi disini peran guru bimbingan dan konseling adalah teman siswa yang selalu siap mendengarkan cerita siswa di manapun dan kapanpun tidak harus di ruangan BK dan dalam keadaan formal, sehingga siswa bisa lebih terbuka untuk menceritakan permasalahan yang menyebabkan siswa tersebut mengalami permasalahan".

Panggilan kepada orang tua siswa yang bermasalah ini, sebagai langkah terakhir guru bimbingan dan konseling. Karenan sebagian siswa yang bermasalah, justru di rumah dia baik-baik saja sehingga orang tua menganggap anaknya tidak ada masalah. Sebagaimana yang dikatakan oleh Ibu Ulianna, S.Pd selaku guru bimbingan dan konseling di SMA Muhammadiyah 09 Kualuhhulu yang penulis wawancarai pada tanggal 9 Mei 2013, menyatakan:

"Sebagai guru bimbingan dan konseling kita selalu memberikan informasi sedikit apapun, seburuk apapun, minimal lewat telepon. Setelah lewat telepon tidak mampu, maka kita mendatangkan orang tua, kalau ingin lebih jelasnya maka orang tua kami mohon untuk menemui guru bimbingan dan konseling, bahwa ada anak yang setiap hari diantarkan oleh orang tuanya sampai ke pintu gerbang sekolah, ketika orang tua pulang, anak tersebut juga ikut keluar dari sekolah. Hal tersebut setiap hari dilakukan oleh orang tua siswa, namun terkadang tiba-tiba orang tua mendapat informasi dari sekolah kalau absensi anaknya tidak memenuhi syarat..."

Faktor Pendukung Dan Penghambat Komunikasi Antarpribadi Antara Guru Bimbingan Dan Konseling Dalam Mengatasi Siswa yang Bermasalah Di SMA Muhammadiyah 09 Kualuhhulu Kabupaten Labuhanbatu Utara.

Untuk dapat melaksanakan bimbingan dan konseling dalam mengatasi siswa yang bermasalah di SMA Muhammadiyah 09 Kualuhhulu Kabupaten Labuhanbatu Utara secara maksimal, maka sebagai guru bimbingan dan konseling dalam pelaksanaan bimbingan tersebut memerlukan pemahaman terhadap karakteristik siswa secara mendalam, di samping itu juga diperlukan dukungan dalam pelaksanaannya dari semua komponen yang ada di sekolah seperti wali kelas, guru dan juga orang tua atau wali murid.

Wali kelas merupakan faktor pendukung bagi pelaksanaan bimbingan dan konseling dalam mengatasi siswa yang bermasalah, karena wali kelas yang lebih tahu catatan-catatan mengenai siswa-siswi yang bermasalah, dari catatan wali kelas guru 
Bimbingan dan Konseling bisa mengetahui absensi, daftar prestasi dan juga catatan-catatan yang lainnya yang diterima dari guru setiap mata pelajaran, sehingga mempermudah guru bimbingan dan konseling untuk mengidentifikasi faktor-faktor penyebabnya. Dalam hal ini, peneliti melakukan wawancara dengan Ibu Ulianna, S.Pd selaku guru bimbingan dan konseling di SMA Muhammadiyah 9 Kualuhhulu yang penulis wawancarai pada tanggal 7 Mei 2013, ungkapannya sebagai berikut:

"Wali kelas juga sangat berperan, karena wali kelas yang lebih tahu catatan-catatan mengenai siswa-siswi yang bermasalah. Setelah itu baru dilihat mana anak-anak yang nilainya di bawah standar kenaikan akan kita panggil. Setelah itu kita tanya apa yang menyebabkan nilai siswa tersebut menjadi rendah, biasanya dalam hal ini guru Bimbingan dan Konseling bekerjasama dengan wali kelas"

Di SMA Muhammadiyah 09 Kualuhhulu Kabupaten Labuhanbatu Utara, terkadang masalah belajar muncul karena gurunya menjelaskan pelajaran maupun metode yang digunakan tidak sesuai dengan karakteristik siswa. Hal-hal semacam itu yang membuat siswa kurang dapat menerima pelajaran yang disampaikan oleh guru, ada juga anak yang menghindari mata pelajaran tertentu, sehingga anak tersebut keluar pada saat jam pelajaran. Untuk menghindari hal-hal semacam itu, maka guru bimbingan dan konseling bekerja sama dengan guru mata pelajaran agar memantau setiap perkembangan siswa di dalam kelas sampai siswa tersebut benar-benar berubah, karena tidak mungkin guru bimbingan dan konseling memantau keadaan siswa di dalam kelas, sehingga diperlukan kerjasama dengan guru tanpa meninggalkan kordinasi antara keduanya. Untuk guru mata pelajaran tertentu yang sering dihindari oleh siswa, guru bimbingan dan konseling memberikan masukan untuk mengubah metode yang digunakan sesuai dengan karakteristik siswa. Dalam hal ini, Ibu Ulianna, S.Pd selaku guru bimbingan dan konseling di SMA Muhammadiyah 09 Kualuhhulu yang penulis wawancarai pada tanggal 10 Mei 2013, di waktu yang sama menambahkan ungkapannya sebagai berikut:

"...karena dalam proses belajar mengajar misalnya, pada mata pelajaran tertentu guru memberikan tes untuk mengetahui apakah siswa sudah bisa menerima pelajaran yang akan diberikan. Post tes untuk mengetahui hasilnya apakah materi ini bisa diterima atau tidak".

Hukuman ini adalah jalan terakhir yang ditempuh dan diperuntukkan bagi siswa yang benar-benar kronis, setelah diberikan bimbingan dan konseling yang dilakukan melalui komunikasi antarpribadi. Adapun hukuman yang diberikan adalah sebagaimana hasil wawancara peneliti dengan Bapak H. Abdul Kamal Munthe, S.H selaku kepala SMA Muhammadiyah 09 Kualuhhulu yang penulis wawancarai pada tanggal 7 Mei 2013:

"Setelah semua solusi itu dijalankan, kalau sudah sembuh dalam arti siswa tersebut sudah tidak mengulangi lagi maka kita biarkan, akan tetapi kalau belum kita buatkan surat pernyataan, berjanji tidak akan mengulangi atau tidak akan meninggalkan kelas lagi dalam waktu atau jam-jam pelajaran. Kalau masih terus dilakukan lagi, kita berikan sanksi yaitu diberikan skorsing, untuk tahap pertama 3 (tiga) hari, tahap kedua 1 (satu) minggu, kalau masih terus dilakukan maka kiat cari solusinya lagi, apakah sudah tidak kerasan di SMA Muhammadiyah 09 Kualuhhulu Kabupaten Labuhanbatu Utara, atau ada masalah yang sangat kronis dengan gurunya atau ada masalah dikelas, maka kita tegaskan sudah tidak mau di SMA Muhammadiyah 09 Kualuhhulu Kabupaten Labuhanbatu Utara atau memperbaiki kesalahannya". 
Akan tetapi peneliti mendapatkan bahwa di SMA Muhammadiyah 09 Kualuhhulu Kabupaten Labuhanbatu Utara jarang sekali siswa tersebut dikeluarkan. Biasanya setelah panggilan orang tua mereka sudah jera dan kembali menjadi baik lagi.

Peranan orang tua sangat penting dalam pelaksanaan bimbingan dan konseling untuk mengatasi siswa yang bermasalah, pelaksanaan bimbingan dan konseling tidak akan maksimal jika tidak ada kerjasama dengan orang tua, karena dengan orang tua ikut proaktif dalam menyelesaikan permasalahan siswa, maka guru bimbingan dan konseling tidak akan kesulitan. Sebagaimana hasil wawancara dengan Ibu Ulianna, S.Pd selaku guru bimbingan dan konseling di SMA Muhammadiyah 09 Kualuhhulu yang penulis wawancarai pada tanggal 10 Mei 2013, ungkapanannya sebagai berikut:

"Dalam hal ini, peranan orang tua juga sangat mendukung, meskipun terkadang ada orang tua yang tidak mau bekerjasama dengan guru Bimbingan dan Koseling, akan tetapi itu hanya sebagian kecil, karena orang tua menyadari bahwa kondisi anak mereka jauh dari orang tua, sehingga mereka proaktif dalam menyelesaikan masalah yang dihadapi oleh anaknya, mereka menyadari penuh dan tidak pernah menyalahkan sekolah malahan mereka menyalahkan anaknya sendiri, terkadang anak tersebut dirumah baik-baik saja, tapi tahutahu orang tua mendapat laporan anaknya mendapat masalah prestasinya..."

Dalam waktu dan kesempatan yang lain Bapak H. Abdul Kamal Munthe, S.H selaku kepala SMA Muhammadiyah 09 Kualuhhulu yang penulis wawancarai pada tanggal 10 Mei 2013 juga mengatakan bahwa:

"Dalam pelaksanaan bimbingan dan konseling di SMA Muhammadiyah 09 Kualuhhulu, selain adanya kerjasama antara guru dan orang tua, fasilitas, sarana dan prasarana juga sangat mendukung pelaksanaan bimbingan dan konseling di SMA Muhammadiyah 09 Kualuhhulu Kabupaten Labuhanbatu Utara, fasilitas tersebut antara lain, ruang khusus bimbingan dan konseling yang dilengkapi dengan komputer, alat komunikasi, surat-surat yang dibutuhkan, buku rekapan untuk mengetahui perkembangan siswa dalam proses belajar yang berupa absensi, daftar nilai maupun administrasi".

Dari hasil wawancara dapat kita ketahui bahwa selain ada kerjasama dengan pihakpihak lain, pelaksanaan bimbingan dan konseling tidak akan maksimal tanpa adanya sarana dan prasarana yang mendukung, dari hasil wawancara tersebut dalam pelaksanaan bimbingan konseling sarana dan prasarana yang mendukung diantaranya adalah: ruang khusus bimbingan dan konseling yang dilengkapi dengan: 1) komputer 2) alat komunikasi 3) surat-surat yang dibutuhkan 4) buku rekapan untuk mengetahui perkembangan siswa dalam proses belajar yang berupa: absensi, daftar nilai juga administrasi. Dengan adanya faktor pendukung yang mempermudah pelaksanaan guru bimbingan dan konseling dalam mengatasi bermasalah di SMA Muhammadiyah 09 Kualuhhulu Kabupaten Labuhanbatu Utara, di sisi lain ada juga faktor penghambat dalam pelaksanan bimbingan dan konseling. Adapun faktor yang menghambat adalah siswa kurang terbuka mengingat karakteristik setiap individu itu berbeda-beda antara individu yang satu dengan individu yang lain, ada yang cenderung bisa lebih terbuka dan menceritakan permasalahannya ketika guru bimbingan dan konseling bertanya, ada juga anak yang datang sendiri kepada guru bimbingan dan konseling untuk meminta solusi masalah yang dihadapinya, akan tetapi kebanyakan jarang yang bisa menceritakan permasalahannya langsung, sehingga membutuhkan proses terlebih dahulu. Dalam hal ini guru bimbingan dan konseling harus benar-benar bisa memahami siswa tersebut. Sebagaimana hasil wawancara peneliti dengan Ibu Ulianna, S.Pd selaku guru bimbingan dan konseling di SMA Muhammadiyah 09 Kualuhhulu yang penulis wawancarai pada tanggal 10 Mei 2013. 
Hasil wawancara dapat kita ketahui bahwa terkadang ada anak yang dipanggil oleh guru bimbingan dan konseling mereka tidak datang, karena mereka beranggapan bahwa dipanggil keruang BK berarti siswa tersebut bermasalah, padahal guru bimbingan dan konseling justru ingin membantu permasalahan yang dihadapi oleh siswa, sehingga berpengaruh terhadap prestasi belajarnya. Dari anggapan-anggapan seperti inilah yang membuat guru bimbingan dan konseling kesulitan dalam mencari tahu faktor-faktor apa yang menyebabkan permasahan siswa tersebut. Ungkapan tersebut senada dengan yang dikemukakan oleh Bapak H. Abdul Kamal Munthe, S.H selaku kepala SMA Muhammadiyah 09 Kualuhhulu. Selain itu kurangnya komunikasi dengan orang tua.

Selain kurangnya keterbukaan siswa untuk menceritakan permasalahannya kepada guru bimbingan dan konseling secara interpersonal, faktor kurangnya komunikasi dengan orang tua juga bisa menjadi penghambat bagi pelaksanaan bimbingan dan konseling dalam mengatasi siswa yang bermasalah. Sebagaimana hasil wawancara peneliti dengan Ibu Ulianna, S.Pd selaku guru bimbingan dan konseling di SMA Muhammadiyah 9 Kualuhhulu yang penulis wawancarai pada tanggal 10 Mei 2013 bahwa:

"Siswa SMA Muhammadiyah 09 Kualuhhulu Kabupaten Labuhanbatu Utara kurang terbuka kepada orang tua, sehingga informasi tentang permasalahan anaknya sangat minim diperoleh akibat berkomunikasi dengan orang tua sangat jarang”.

Secara umum, upaya bimbingan dan konseling di SMA Muhammadiyah 09 Kualuhhulu Kabupaten Labuhanbatu Utara dalam mengatasi siswa yang bermasalah tidak jauh berbeda dengan upaya yang dilakukan terhadap siswa yang mempunyai masalah lain di sekolah lain. Adapun tahap-tahap tersebut adalah mengenali siswa yang bermasalah secara intensif

Dengan adanya komunikasi antarpribadi siswa dan guru bimbingan dan konseling, dapat diketahui apa saja yang menjadi penyebab siswa tersebut mengalami permasalahan dalam belajar, Sehingga guru bimbingan dan konseling bisa menetapkan bidang kecapakan tertententu yang dianggap bermasalah dan memerlukan perbaikan. Bidang-bidang kecakapan ini dapat dikategorikan menjadi tiga macam (Syah, 2006:176) yskni bidang kecakapan bermasalah yang dapat ditangani oleh guru sendiri, bidang kecakapan bermasalah yang dapat ditangani oleh guru dengan bantuan orang tua dan bidang kecakapan bermasalah yang tidak dapat ditangani oleh guru maupun orang tua. Pada pemaparan di atas telah dijelaskan faktor-faktor yang menyebabkan siswa mengalami masalah dalam belajar yaitu: 1) faktor lingkungan yang meliputi, lingkungan keluarga, lingkungan sekolah, dan lingkungan masyarakat. 2) faktor yang timbul dari dalam diri siswa itu sendiri.

Dalam menetapkan usaha-usaha bantuan yang dilakukan guru bimbingan dan konseling menyesuaikan dengan latar belakang masalah yang dialami siswa, banyak alternatif yang dapat diambil guru bimbingan dan konseling dalam mengatasi siswa yang bermasalah, akan tetapi sebelum pilihan tertentu diambil. Berdasarkan hasil riset penulis selama melakukan penelitian di SMA Muhammadiyah 09 Kualuhhulu Kabupaten Labuhanbatu Utara, guru bimbingan dan konseling terlebih dahulu melakukan beberapa langkah penting sebagai berikut yakni menganalisis hasil diagnosis, yakni menelaah bagian-bagian masalah dan hubungan antarbagian dari data-data yang diperoleh untuk memperoleh pengertian yang benar mengenai permasalahan dalam belajar yang dihadapi siswa, mengidentifikasi dan menentukan bidang kecakapan tertentu yang memerlukan perbaikan dan menyusun program perbaikan. Setelah langkah-langkah di atas selesai, maka guru bimbingan dan konseling bisa menentukan apakah siswa tersebut membutuhkan 
terapi dan bimbingan ataukah program perbaikan untuk memperbaiki prestasinya yang rendah, kemudian setelah itu guru bimbingan dan konseling melaksanakan langkah selanjutnya, yaitu melaksanakan program bantuan terhadap siswa yang bermasalah dalam belajar.

\section{Kesimpulan}

Penelitian ini menghasilkan kesimpulan bahwa bentuk komunikasi antara guru bimbingan dan konseling dan siswa yang bermasalah di SMA Muhammadiyah 09 Kualuhhulu, berupa komunikasi verbal dan komunikasi nonverbal. Komunikasi verbal yang dilakukan guru bimbingan dan konseling di SMA Muhammadiyah 09 Kualuhhulu Kabupaten Labuhanbatu Utara yaitu dengan cara mengkomunikasikan pesannya secara verbal atau dengan lisan melalui program pembelajaran yang telah ditetapkan, sedangkan komunikasi nonverbal antara siswa dan guru terjadi sebagai proses pertukaran pikiran dan gagasan dimana pesan yang disampaikan berupa isyarat, ekspresi wajah, pandangan mata, gerakan tubuh dan sentuhan.

Efektivitas komunikasi antara guru bimbingan dan konseling dan siswa yang bermasalah di SMA Muhammadiyah 09 Kualuhhulu adalah efektif, karena komunikator memiliki kredibilitas (source credibility), pesan yang sampaikan dirancang dengan sedemikian rupa sehingga menarik bagi siswa, dapat dipahami oleh siswa, dan sesuai dengan kebutuhan siswa. Selain itu, komunikan (siswa) juga mau mendengarkan atau berkonsentasi agar pesan dapat diterima dengan benar, sehingga siswa bersedia mengambil keputusan pada saat komunikasi berlangsung dan memberikan umpan balik kepada guru.Langkah-langkah penanganan yang dilakukan guru bimbingan dan konseling terhadap siswa yang bermasalah di SMA Muhammadiyah 09 Kualuhhulu melalui tahapan-tahapan berikut: mencari data siswa-siswi, siswa dipanggil ke ruang BK secara pribadi atau didatangi ke rumahnya, memberikan surat peryataan kepada siswa, panggilan orang tua, faktofaktor yang menjadi pendukung dan penghambat komunikasi antarpribadi antara guru bimbingan dan konseling dalam mengatasi siswa yang bermasalah di SMA Muhammadiyah 09 Kualuhhulu adalah faktor pendukung, wali kelas, guru, hukuman, orang tua atau wali murid, sarana dan prasarana, faktor penghambat, siswa kurang terbuka, kurangnya komunikasi dengan orang tua. Selain itu, upaya guru bimbingan dan konseling dalam mengatasi siswa yang bermasalah dengan cara mendiagnosis permasalahan penyebab masalah yang terjadi pada siswa-siswi.

\section{DAFTAR PUSTAKA}

Ali, Deli. (2000), Kamus Lengkap Bahasa Indonesia, Bandung: Ganeca Grafic

Altman, I. and Taylor, D. A. (2005), Social Penetration, New York Holst, Rinehart, Winston

(2005), Communication in Interpersonal Relationships: Social Penetration

Theory. In M. E. Roloff and G. R. Miller (Eds.), Interpersonal processes: New

directions in communication research, 257-277. Newbury Park, CA, Sage.

Azra, Azyumardi. (2005), Pendidikan Islam dan Modernisasi Menuju Millenium Baru, Logo, Jakarta.

Azwar, S. (2003). Pengantar Psikologi Intelegensi. Yogyakarta: Pustaka Pelajar. 
Budyatna, Muhammad \& Ganiem. (2011), Teori Komunikasi Antarpribadi, Jakarta, Prenada.

Daymon, Christine dan Immy Holloway, 2008, Metode-Metode Riset Kualitatif dalam Public Relations \& Marketing Communications, Penerbit Bentang Pustaka, Yogyakarta

Djaali. (2007), Psikologi Pendidikan, PT. Bumi Aksara, Jakarta.

Gerungan, WA.(2004), Psikologi Sosial, Refika Aditama, Bandung

Griffin, Emory A. (2003), A First Look at Communication Theory, 5th edition, McGrawHill, New York.

Hafid, Cangara. (2006), Pengantar llmu Komunikasi, Rajawali Pers, Jakarta.

Handoko, T.H. (2006), Manajemen Personalia dan Sumber Daya Manusia, Edisi 2, Yogyakarta: BPFE

Hasan, Iqbal. (2002), Pokok-Pokok Materi Metodologi Penelitian dan Aplikasinya. Yogyakarta: Pustaka Pelajar.

Hasyim, Ahmad. (2002). Hubungan Antara Komunikasi Interpersonal Guru-Siswa dengan Pembinaan Akhlak di SLTP Muhammadiyah 8 Yogyakarta. Tesis. Sunan Kalijaga. Yogyakarta.

Iriantara, Yosal. (2006), Public Relation Writing, Pendekatan Teoritis dan Praktis. Bandung: Simbioasa Rekatama Media

Kabalmay, H. (2002), MetodePenelitian Kuantitatif Kualitatif. Bandung: Alfabeta

Kholil, Syukur. (2011), Teori Komunikasi Massa, Medan: Perdana Mulya Sarana

Koesoema, Doni. (2009), Pendidikan Karakter di Zaman Keblinger, Grasindo, Jakarta.

Mandona, Astri. (2012). Interaksi Edukatif Guru dengan Siswa dalam Pembelajaran AlQur'an Hadits guna Meningkatkan Motivasi Belajar di MTs N Sleman Kota. Tesis. UIN Sunan Kalijaga. Yogyakarta.

Miller, Katherine. (2001), Communication Theory: Perspectives, Processes, and Contexts, Library of Congress Cataloging-in-Publication Data, USA

Moleong, Lexy J, (2005), Metode Penelitian Kualitatif, Bandung: Remaja Rosdakarya Mulyadi. (2008), Diagnosis Kesulitan Belajar dan Bimbingan terhadap kesulitan belajar khusus, Nuha Litera, Yogyakarta. 
Mulyana, Deddy, (2002), Ilmu Komunikasi Suatu Pengantar, Bandung: Remaja Rosdakarya

Prayitno. (2004), Dasar-Dasar Bimbingan dan Konseling, Rineka Cipta, Jakarta.

Rosanti, Mela.(2012). Motivasi Belajar Matematika Siswa Kelas III MI Ma'arif Klangon ditinjau dari Pemberian Reward dan Reinforcement. Tesis. UIN Sunan Kalijaga. Yogyakarta.

Sarwono. S.W. (2011), Psikologi Remaja, Jakarta: PT Raja Grafindo Persada.

Sugiono. (2010), Metode Penelitian Kuantitatif Dan R\&D, Bandung: Alfabeta.

Suranto. (2010), Komunikasi Sosial Budaya, Yogyakarta: Graha Ilmu.

Syah, Muhibbin. (2006), Psikologi Pendidikan Dengan Pendekatan Baru, Bandung: PT.Remaja Rosdakarya.

Walgito, Bimo. (2004), Bimbingan dan Konseling (Study dan karir), Yogyakarta: Andi Offset

Wiryanto, (2005), Pengantar Ilmu Komunikasi, Jakarta: PT Gramedia Widiasarana Indonesia, Jakarta. 